\title{
BeCAUSE OF History, PHILOSOPHY, THE CONSTITUTION, FAIRNESS \& NEED: WHY AMERICANS Have a Right to National Health CaRe
}

\author{
Kenneth Shuster
}

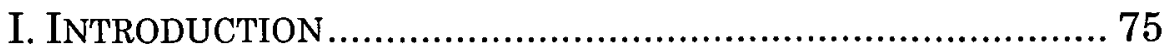

II. A BRIEF History of Health CARE COVERAGE IN THE UNITED STATES ........................................................... 76

III. A Right To HEALTh CARE UNDER The CONSTITUTION . 85 IV. Ways to Provide Access to National Health Care 93 V. ARGUMENTS Against NATIONAL Single-PAYER HEALTH CARE ............................................................. 97 VI. How a National Health CARE Program Should Be FUNDED ……........................................................ 102 VII. PHILOSOPHICAL ISSUES AND QUESTIONS OF FAIRNESS

OVER NATIONAL HEALTH CARE ..................................... 104 VIII. CONCLUSION ....................................................... 115

\section{INTRODUCTION}

This article examines the present state of health care in the United States, as well as the history of such care, and health insurance generally, and claims that access to health care is a right to which Americans are entitled. It also looks to how national health care should be implemented. ${ }^{1}$ Such

* The author, a rabbi and attorney, received his rabbinical ordination from the Rabbi Isaac Elchanan Theological Seminary, an M.S. in Jewish Philosophy from Yeshiva University, a J.D. from New York Law School, and an LL.M. from NYU School of Law. He is an expert in comparative Talmudic and American law and Jewish medical ethics, and has published numerous articles on Talmudic and American law, and comparative Talmudic and American law. The author thanks Professor Mark E. Brandon, of the Vanderbilt Law School, for his assistance. This article is dedicated to Gary N. Lerner, M.D.

1 It may not initially be apparent in a paper devoted to finding a right to healthcare why we need to ask how such a right should be executed. However, as we will see, the major problem Americans face when it comes to health care is not lack of health care - insurance plans 
an examination is important, for according to the latest Gallup poll, as of December 2011, close to 20\% of Americans over the age of twenty lack health insurance. ${ }^{2}$ This lack of insurance, according to conservative estimates, costs United States' taxpayers, in the form of government programs, forty-two billion dollars a year. ${ }^{3}$ Moreover, many insured Americans are presently not able to pay all of their medical bills due to copayments, deductibles, and exorbitant medical costs. ${ }^{4}$ To better appreciate why this reality exists I provide a brief history of health care and attempts at health care reform in the United States.

\section{A Brief History of Health CaRe Coverage in the UNITED STATES}

Health insurance as we know it was first available in this country in the $1920 \mathrm{s.}^{5}$ Before then, no attempt to

exist in abundance - but affordable access to health coverage. Therefore, even if health care is found to be a legal right, the problem of the uninsured or underinsured can only be rectified by the manner and degree to which it is made available to Americans.

2 Jon Walker, Number of Uninsured Americans Steadily Increasing, FDL ACTION (Jan. 24, 2012, 8:58 AM), http://fdlaction. firedoglake.com/2012/01/24/number-of-uninsured-americans-steadilyincreasing (last visited Feb. 6, 2013).

3 The Uninsured, AETNA, https://www1.aetna.com/about-aetnainsurance/public-policy-perspectives/uninsured.html (last visited Oct. 13, 2012) [hereinafter AETNA].

4 Cathy Schoen et al., How Many are Underinsured? Trends Among U.S. Adults, 2003 and 2007, The Commonwealth Fund (June $10, \quad 2008), \quad$ http://www.commonwealthfund.org/Publications/In-theLiterature/2008/Jun/How-Many-Are-Underinsured--Trends-Among-U-S-Adults-2003-and-2007.aspx (last visited Oct. 13, 2012) (stating that in health care parlance, such individuals, who numbered 25 million in 2007, are underinsured); Richard L. Brandt, Almost Half of Americans Can't Pay Their Medical Bills?, ENTREPRENEUR WATCH (March 12, 2010), http://richardbrandt.blogs.com/entrepreneurwatch/ 2010/03/almost-half-of-americans-cant-pay-their-medical-bills.html (last visited Feb. 6, 2013).

5 Melissa Thomasson, Health Insurance in the United States, EH.NET (Feb. 1, 2010), http://eh.net/encyclopedia/article/thomasson. insurance.health.us (last visited Oct. 13, 2012). 
provide extended health coverage was successful. ${ }^{6}$ There are many reasons for this. First, before the 1920s, insurance companies saw no need to provide wide coverage because most individuals believed they did not require it. ${ }^{7}$ Without a perceived need, and resultant profits, and the reality that applicants could lie about their health status, insurance companies viewed individual health coverage as an unacceptable financial risk. ${ }^{8}$ Moreover, without the means to calculate health risks in individual circumstances, insurance companies could not accurately assess premiums. ${ }^{9}$ Second, because society lacked many modern medical cures and technology,10 the need for health

6 Brian Palmer, Obama Says Theodore Roosevelt Lobbied for Health Care Reform . . . , Slate Magazine (March 9, 2010), http://www.slate.com/articles/news_and_politics/explainer/2010/03/obam a_says_theodore_roosevelt_lobbied_for_health_care_reform_.html (last visited Oct. 13, 2012) (asserting that attempts to provide expanded health care prior to the 1920 s included lobbying by President Theodore Roosevelt during his 1912 "Bull Moose" campaign and proposals enacted by the American Association for Labor Legislation); Bill Meyer, National Health Care Debate Goes Back to Theodore Roosevelt Plan in 1912: Analysis, Cleveland. COM (Aug. 12, 2009), http://www .cleveland.com/nation/index.ssf/2009/08/national_health_care_debate_ha .ht; Thomasson, supra note 5 , at 1 (noting that proposals by the American Association for Labor Legislation were never enacted).

7 Thomasson, supra note 5, at 1 (asserting that before 1920 most people did not feel they needed health insurance); Stephanie Kelton, $A n$ Introduction to the Health Care Crises in America: How Did We Get Here?, CFEPS (Sept. 2007), http://www.Cfeps.org/health/chapters/ $\mathrm{html} / \mathrm{ch} 1 . h \mathrm{tm}$ (stating that there was no market for health insurance throughout the nineteenth century due to medical care being provided at home).

8 Thomasson, supra note 5, at 1 (declaring that commercial insurance companies were unwilling to offer private health insurance); John T. Preskitt, Health Care Reimbursement: Clemens to Clinton, NCBI (Jan. 2008), http://www.ncbi.nlm.nih.gov/pmc/articles/ PMC2190551/ (last visited Feb. 6, 2013) (emphasizing that insurance companies were unwilling to insure due to inability to calculate health risks).

9 Preskitt, supra note 8 , at 40 (stating that insurance companies lacked the information to write premiums); Thomasson, supra note 5 , at 1 (stating that insurance companies felt they lacked the information to accurately write premiums).

10 For example, insulin and sulfa, used to treat diabetes, were not discovered until 1922 and 1935, respectively, penicillin was not 
insurance prior to 1920 was not as important as it is today because the average American did not need to spend a lot on medical care. ${ }^{11}$ When they thought to have others pay their expenses, most individuals cared about sickness insurance and funeral costs, which many employers and insurance companies covered. ${ }^{12}$

Thirdly, in addition to insurance companies, physicians and pharmacists opposed individual health insurance because they felt it would limit their fees and undermine their businesses. ${ }^{13}$ Beginning in the 1920 s, the health care landscape started to change. Due to the progress in medical cures and technology (which were due in large part to increased machines and treatment modalities) that were more appropriate in hospital settings than residences, the locus of treatment shifted from homes to hospitals. ${ }^{14}$ Moreover, many states started to require more extensive licensing and training requirements for doctors. ${ }^{15}$ As a

discovered until 1928, and large-scale production of penicillin did not happen until after World War II, a vaccine for polio was not created until 1955, the iron-lung machine was not developed until 1928, and the electroencephalogram was first used in 1929. See Thomasson, supra note 5, at Table 1 (stating that insulin fashioned in 1922, sulfa developed in 1935, and the polio vaccine was discovered in 1955); Tim Lambert, $A$ Brief History of Medicine, http://www .localhistories.org/medicine.html (last visited Oct. 13, 2012) (noting that penicillin was discovered in 1928, electroencephalogram was first used in 1929, and the iron-lung machine was invented in 1928).

11 Thomasson, supra note 5 , at 1 (proclaiming that because of the rudimentary state of medical technology before 1920 , people had low medical expenditures).

12 Id. (noting that households purchased sickness insurance); Palmer, supra note 6, at 2 (noting that fraternal orders had profitable burial insurance programs); Preskitt, supra note 8 , at 40 (noting that burial insurance was a significant part of insurance company business in the early 1900s).

13 Preskitt, supra note 8, at 40 (affirming that physicians and pharmacists opposed insurance).

14 See Thomasson, supra note 5, at 1-2 (stating that advances in medical technology along with a view of medicine as a science encouraged sick people to visit doctors and hospitals); Preskitt, supra note 8, at 41 (noting that advances in medical technology caused the sick to visit doctors and hospitals).

15 See Thomasson, supra note 5 , at 2 (stating that increasing requirements for licensure and accreditation led to higher medical 
result of such higher standards in the practice of medicine, many medical schools closed, which caused a shortage of doctors, although the demand for medical care itself increased. 16

All of these factors caused the price of medical care to rise precipitously. In 1929, this led some teachers in Dallas, Texas to create a prepaid hospital insurance plan that covered a three-week hospital stay at a fixed cost of six dollars. ${ }^{17}$ This was the first case of health insurance, as we know it, in the United States. Throughout the 1930s, such prepaid plans were popular with the public who saw them as protection from ever-increasing bills, and with hospitals, which viewed them as a much-needed source of revenue. ${ }^{18}$ In the early 1930s, Blue Cross, inspired by the success of these plans, began to provide broader hospital insurance for working Americans. By the late 1930s, Blue Shield instituted health insurance to cover doctor visits. ${ }^{19}$ Such plans were additionally valuable because they allowed

costs); Preskitt, supra note 8, at 41 (affirming that increased requirements for licensure, education and accreditation put upward pressure on the costs of physicians' services); see also Ronald Hamowy, The Early Development of Medical Licensing Laws in the United States, 1875-1900, http://mises.org/journals/jls/3_1/3_1_5.pdf (The need for such licensure requirements is easily appreciated when one realizes that it was not until 1889 that any American state (Florida) required prospective doctors to obtain both a medical school diploma and pass a licensing examination. Also, until 1915, Alabama, Colorado, and New Mexico did not require doctors to attend medical school.).

16 Duke University Medical Students, The History of Medical Schools in the U.S., VAULT.COM, http://www.vault.com/wps/portal/usa/vcm/detail/Career-

Advice/Education-Advice/The-History-of-Medical-Schools-in-the-

U.S.?id=5586\&filter_type $=0 \&$ filter_id=0 (last visited Oct. 13, 2012) (proclaiming that the proposal of a four-year medical school curriculum resulted in the closure of many medical schools).

17 Id. at 2 (In 1929, a group of Dallas teachers contracted with Baylor University Hospital to provide twenty-one days of hospitalization for a fixed rate of six dollars.).

18 Thomasson, supra note 5, at 2 (stating that pre-paid hospital plans were mutually desirable to hospitals and subscribers during the 1930s).

19 Id. at 2-3; see also Preskitt, supra note 8, at 2 (asserting that Blue Cross provided hospital insurance and Blue Shield covered physician services). 
employers to deduct the cost of employee health premiums and exempted employees from having to pay a tax on the benefit. ${ }^{20}$

The 1940s ushered in a "golden age of medicine" due to expanded medical knowledge and prestige, improved hospital hygiene, and further advances in medical and scientific technology. ${ }^{21}$ Because of such advances in medical care, and the fact that health insurance was not taxable to beneficiaries and was deductible to payees, by $1958,75 \%$ of Americans had some form of private health insurance. ${ }^{22}$

However, because health insurance at this time amounted in the main to coverage for employees, an entire segment of the population, including the poor, unemployed, self-employed, and retired, received no health coverage. ${ }^{23}$ To remedy this, the government introduced first Medicare and then Medicaid in the $1960 \mathrm{~s} .{ }^{24}$ Medicare is governmentsponsored insurance that is made up of two parts. Part A covers hospital costs for all Americans as soon as they reach sixty-five. Part B is a supplement to Part A that pays for seniors' doctor bills. ${ }^{25}$ Medicaid provides the same coverage to the indigent. ${ }^{26}$

By 1970 , as a result of more Americans being covered because of Medicare, Medicaid, and private insurance, the

20 Preskitt, supra note 8 , at 3 (stating that employers did not have to pay taxes on money contributed and employees did not have to pay tax on the benefit).

21 Dennis L. Hufford, Managed Care: Managing the Monster, USAFP.ORG (July 13, 1999), http://www.usafp.org/Fac_Dev/Leadership_ Management/Managed\%20Care/Managed-Care-TTP-handout.htm (last visited Oct. 13, 2012).

22 Preskitt, supra note 8 , at 3 (noting that in $1958,75 \%$ of Americans were privately insured).

23 How Did Healthcare Come About in the United States?, STAY SMART, STAY HEALTHY, http://www.staysmartstayhealthy.com/health_ care_history_inthe_united_states (last visited Oct. 13, 2012) [hereinafter STAY SMART, STAY HEALTHY].

24 Thomasson, supra note 5, at 5; see also History of Health Care Financing in the USA, HEALTH ECONOMICS, at 11-12, http://www. pharmpress.com/files/docs/health_economics_sample.pdf [hereinafter History of Health Care Financing in the USA].

25 Thomasson, supra note 5, at 5; STAY SMART, STAY HEALTHY, supra note 24 , at 3 .

26 STAY SMART, STAY HEALTHY, supra note 23, at 3. 
United States was spending over seventy billion dollars a year on health care. ${ }^{27}$ In an attempt to control these costs, in 1973, Congress passed the Health Maintenance Organization (HMO) Act. ${ }^{28}$ Although the first HMOs were introduced to reign in the Federal Government's health expenditures, by 1975 there were 178 HMOs in the United States, providing close to six million individuals with private insurance. ${ }^{29}$

In the 1980s, managed care expanded greatly in three ways. First, through preferred provider organizations (PPOs), which combined "fee-for-service" protocols, whereby patients could choose to have doctors attend them who are not themselves members of the patients' HMO, with HMO coverage. Second, point of service (POS) plans were created, which are similar to PPO plans in that they permit patients to visit out-of-network providers, but which differ from PPO plans in that POS plans have two schedules of benefits coverage depending on whether a treating doctor is in or out of network. ${ }^{30}$ Third, exclusive provider organizations (EPOs) arrived, which function like small PPOs, except that consumers can choose to deal directly with doctors within a group instead of individual in-network doctors; some EPO plans will pay partial reimbursements to patients who go outside their network in emergencies. ${ }^{31}$ Health maintenance organizational health care has proven to be a huge mistake because all three of the above manifestations of its coverage, combined with the generally high cost of medical care, have priced many individuals out of the health care market. ${ }^{32}$ As of 2010 , the number of uninsured

27 History of Health Care Financing in the USA, supra note 24, at 12.

$28 \quad I d$. at 13.

29 Id. at 14.

30 Id. at $17-18$.

31 Id; see also EPO Insurance: What is an EPO Insurance Plan?, MAMA'S HEALTH, http://www.mamashealth.com/insurance/epo.asp (last visited Oct. 13, 2012).

32 See History of Health Care Financing in the USA, supra note 24, at 24; Les Christie, Number of People Without Health Insurance Climbs, CNN MoNEY (Sept. 13, 2011, 5:22 PM), http://money. 
Americans was close to fifty million, or $16.3 \%$ of the population. ${ }^{33}$ Often, this is not only due to the increased cost of premiums, but to ever-increasing deductibles and copayments that many, if not most, insurance plans require. ${ }^{34}$ Numerous attempts have been made over the years to reform aspects of national health care so that the problems so many Americans have with health care could be avoided. In the past one hundred years alone, many American presidents including both Roosevelts, Truman, Kennedy, Johnson, Nixon, Ford, Clinton, and Obama, have examined various avenues to remedy our present health care crisis. ${ }^{35}$ Unfortunately, most of these initiatives have failed. ${ }^{36}$ However, some have succeeded. In addition to

cnn.com/2011/09/13/news/economy/census_bureau_health_insurance/ind ex.htm (last visited Oct. 13, 2012).

33 Christie, supra note 32 , at 1.

34 Robert Reich, "The Wrong Way to Save Money on Healthcare," (Sept. 14, 2012), http://www.guernicamag.com/daily/robert-reich-thewrong-way-to-save-money-on-healthcare.

35 Meyer, supra note 6 (asserting that Theodore Roosevelt advocated for national health care in his last "Bull Moose" campaign); History of Health Care Financing in the USA, supra note 24, at 7-22; Kate Pickert, The Unsustainable U.S. Health Care System, TIME SWAMPLAND (Feb. 4, 2010), http://swampland.time.com/2010/02/04/theunsustainable-u-s-health-care-system/ (stating that Obama desires to pass health reform legislation); Walker, supra note 2 (noting that one of Obama's biggest accomplishments is his health insurance reforms).

36 Reasons for this failure include the opposition that physicians, pharmacists, insurance companies, and powerful lobbyists like the American Medical Association have had to most national health care proposals. See History of Health Care Financing in the USA, supra note 24, at 9 (stating that the AMA opposed national health insurance); Thomasson, supra note 5 (asserting that physicians, pharmacists and insurance companies opposed compulsory health insurance). Other reasons include ideological and philosophical differences between Republicans and Democrats, the fact that many individuals do not understand the complexities of the issues involved, and fear of communism. See also Catherine Hoffman, National Health Insurance A Brief History of Reform Efforts in the U.S., The HENRY J. KAISER FAMILY FOUNDATION (March 2009), http://www.kff.org/healthreform/ upload/7871.pdf (stating that national health insurance proposals failed due to issue complexity, ideological differences, and special interest group lobbying, that opponents of national health care reform used fear of socialism and communism, and that political opposition was more organized than that which favored health reform). 
Medicare and Medicaid, such measures include the Social Security Act of 1935, to the extent it factored the cost of medical care into an individual's monthly assistance copayments, ${ }^{37}$ and the Employee Retirement Income Security Act (ERISA) of 1974, which expanded health coverage to protect the fringe benefits of employees. ${ }^{38}$ ERISA is a greatly modified form of national health coverage, for it overrules state employee regulations when employers use it to self-insure. ${ }^{39}$ In 1979 , Medicaid was expanded to include coverage for children and expectant mothers ${ }^{40}$ and in 1986 the Consolidated Omnibus Budget Reconciliation Act (COBRA) was passed, which required employers to continue to provide health insurance to employees for a period after their employment ends. ${ }^{41}$

In 1996, Congress expanded ERISA and COBRA under the Health Insurance Portability and Accountability Act (HIPAA) to allow workers to exchange their insurance plans while employed and be covered under new plans if they lose their jobs. ${ }^{42}$ Although HIPAA amounted to a godsend for American workers, it had the drawback of enormously high deductibles. ${ }^{43}$ Finally, President Obama signed the Patient Protection and Affordable Care Act (PPACA) into effect on March 23, 2010.44 This act's provisions will become binding

37 History of Health Care Financing in the USA, supra note 24, at 7; Thomasson, supra note 5 (stating that Social Security was viewed as a logical means of providing national health care).

38 History of Health Care Financing in the USA, supra note 24, at 14-15 (emphasizing that the original purpose of ERISA was to protect worker's fringe benefits).

$39 \quad I d$. at 15 (affirming that courts interpret ERISA to override state regulation of employee insurance plans when employers are selfinsured).

40 Id. at 17 (declaring that Medicaid widened to include coverage for pregnant women and children).

41 Id. at 18 (noting that COBRA covers workers after employment termination).

$42 I d$. at 20 (noting that HIPAA's focus is to make insurance portable and continuous for employees).

43 Id. at 20 (stating that HIPAA deductibles in 1996 went from $\$ 1,600$ to $\$ 2,400$ for individuals and $\$ 3,200$ to $\$ 4,800$ for families).

44 Fact Sheet: The Affordable Care Act's New Patient's Bill of Rights, HEALTHREFORM.GOV (June 22, 2010), http://healthreform. gov/newsroom/new_patients_bill_ 
over time and it will not be fully implemented until at least 2014.45 It dictates that Americans cannot be denied coverage for pre-existing conditions, ${ }^{46}$ will have no lifetime limits on coverage, ${ }^{47}$ and will have no copayments or deductibles for routine preventive care like colonoscopies, mammograms, and immunizations. ${ }^{48}$ This history shows that (1) national health care for all Americans is possible, (2) the government is finally moving in the right direction when it comes to national health care, and (3) the federal government has authority and power over health care in this country. The fact that the Supreme Court, in June 2012, ruled that the Affordable Care Act is constitutional ${ }^{49}$ affirms this and may be used to position the PPACA as a giant step in the right direction toward some form of national health care, which the government is entitled to provide to Americans. ${ }^{50}$ Before we address the most ideal

of_rights.html [hereinafter Fact Sheet: The Affordable Care Act's New Patient's Bill of Rights]; see also The Affordable Care Act, Section by Section, HEALTHCARE.Gov, http://www.healthcare.gov/law/full (last visited Oct. 13, 2012).

45 Fact Sheet: The Affordable Care Act's New Patient's Bill of Rights, supra note 44 (noting that most of the act's protections will apply in full to all Americans starting in 2014); see generally Health Reform in Action, The White House, http://www.whitehouse.gov/ healthreform/healthcare-overview (last visited Oct. 13, 2012) (claiming that benefits, protections, and savings will be implemented between now and 2014).

46 Fact Sheet: The Affordable Care Act's New Patient's Bill of Rights, supra note 44 , at 2 (establishment of pre-existing insurance plan).

47 Id. at 1-2 (noting that insurance companies can no longer place a lifetime limit on coverage).

$48 \quad I d$. at 2 (stating that the act covers select preventive services without charging out of pocket costs).

49 Specifically, the Court held that the "individual mandate" portion of the PPACA, which requires all Americans to purchase some form of health insurance, does not invalidate the rest of the Act. This is because the mandate may be viewed as a "tax" which Congress has the power to levy and not a penalty. See Nat'l Fed'n of Indep. Bus. v. Sebelius, 132 S. Ct. 2566 (2012) (holding that the individual mandate may be construed as a tax and not a penalty).

50 The commerce power, derived from the Commerce Clause, is a principle reason the government may constitutionally provide Americans with national health care. In Wickard v. Filburn, the Court 
manner in which such care should be delivered to Americans, we first examine whether Americans have a right to health care under the Constitution. ${ }^{51}$

\section{A Right To Health CARE Under The Constitution}

Although the Supreme Court has yet to found a righto government sponsored health care that individuals need not pay for themselves, the Court has found that, in certain circumstances, the government must provide health care to

held that "the power to regulate interstate commerce includes the power to regulate the prices at which commodities in that commerce are dealt in and practices affecting such prices." 317 U.S. 111, 128 (1942). If this is true of wheat grown with the intention to be wholly consumed intrastate, scholars contend that insurance coverage which is sold interstate also comes within the Commerce Clause's grant of federal governmental authority. See Jeremy Leaming, Opponents of Health Care Law Rely on Wobbly Federalism Argument for a Reason, AMERICAN CONSTITUTION SOCIETY FOR LAW AND POLICY (Feb. 8, 2012), http://www.acslaw.org/acsblog/opponents-of-health-care-law-rely-onwobbly-federalism-argument-for-a-reason (last visited Oct. 19, 2012) (Southern California law professor Rebecca L. Brown believes that as $17 \%$ of the Unites States economy participates in the health care market, the question of health insurance definitely falls under the commerce clause.); Carrie Dann, Is The Health Care Law Constitutional? MSNBC (Feb. 4, 2011), http://www.msnbc.msn. $\mathrm{com} / \mathrm{id} / 41424402 / \mathrm{ns} /$ politics-more_politics/t/ health-care-law-constitution (Law professor Charles Fried says the health insurance market clearly falls under the Commerce Clause.). The Commerce Clause of the United States Constitution states, "The Congress shall have power . . . To regulate Commerce with foreign Nations, and among the several States, and with the Indian Tribes." U.S. ConsT. art I, § 8, cl. 3. Although the Court held that the Affordable Care Act is not a proper use of the Commerce Clause, Nat'l Fed'n of Indep. Bus., 132 S. Ct. at 2589 (stating that "the Framers gave Congress the power to regulate commerce, not to compel it") (emphasis in original), this was not because the Court believed the Act cannot come under the Clause per se, but because the Act's individual mandate attempts to compel, and not regulate, activity. Id. at 2587 ("The individual mandate, however, does not regulate existing commercial activity. It instead compels individuals to become active in commerce by purchasing a product.") (emphasis in original).

51 The Supreme Court in Nat'l Fed'n of Indep. Bus., did not grant Americans a right to national health care. It ruled that the individual mandate portion of the PPACA exceeded Congress's power under the Commerce Clause. 132 S. Ct. at 2589. 
prisoners because it would violate the Eighth Amendment's ban on "cruel and unusual punishment" to not do so. ${ }^{52}$ The first argument then in favor of a health care plan that is available to all Americans, regardless of their ability to pay, is an equal protection argument. Just as prisoners must be provided with health care although they cannot pay for it themselves, all Americans who cannot afford health insurance on their own must be provided with health care. ${ }^{53}$ This should be the case even if the Court employs a "rational basis" and not a "strict scrutiny" standard to find such an equal protection based health care right. ${ }^{54}$

52 See Estelle v. Gamble, 429 U.S. 97, 101-08 (1976) (stating that deliberate indifference by prison personnel to a prisoner's serious illness or injury is cruel and unusual punishment). The fact that government officials must provide health care in certain cases to prisoners, informs a right to health care by a segment of the population. The Eighth Amendment to the Constitution states, "Excessive bail shall not be required, nor excessive fines imposed, nor cruel and unusual punishment inflicted." U.S. CONST. amend. VIII.

53 Equal protection arguments derive from the Fourteenth Amendment to the Constitution, which states in part, "nor shall any State deprive any person of life, liberty, or property without due process of law; nor deny to any person within its jurisdiction the equal protections of the law." U.S. CONST. amend. XIV, § 1. Although the Fourteenth Amendment applies on its face only to the states and not the federal government, the Supreme Court has held that intentionally discriminatory federal practices may violate the due process clause of the Fifth Amendment and be comparable to state equal protection violations. See Bolling v. Sharpe, 347 U.S. 497, 499 (1954) (concepts of equal protection and due process are not mutually exclusive). Put differently, the Due Process Clause fights federal discrimination the same way the Equal Protection Clause combats state discrimination. The Fifth Amendment to the Constitution states that "No person shall be ... deprived of life, liberty, or property, without due process of law." U.S. Const. amend. 5.

54 The Supreme Court follows a three-tiered protocol to discover whether equal protection and due process rights have been violated. See Doug Linder, Exploring Constitutional Conflicts: Levels of Scrutiny under the Equal Protection Clause, EXPLORING CONSTITUTIONAL LAW (2012), http://law2.umkc.edu/faculty/projects/ftrials/conlaw/

epcscrutiny.htm (last visited Oct. 19, 2012). The strictest level of review, as seen from the perspective of the alleged victim, is "strict scrutiny." Id. Under this standard, a law that protects some persons, but not others who are "similarly situated," is legal only if it is necessary to serve a compelling government interest. Id. The Court 
uses an "intermediate" or "middle" level scrutiny to examine whether alleged discrimination is substantially related to an important government interest. Id. Finally, the Court uses a "rational basis" or "minimum" scrutiny to find whether a challenged classification rationally serves a legitimate government interest. Id. The Court uses different levels of scrutiny depending on the suspect classification involved, in other words, whether a government policy discriminates against a maximally or minimally constitutionally protected group of individuals. For example, strict scrutiny seeks to protect fundamental rights in the context of equality and autonomy and readily applies to race, national origin, and religion. See LAURENCE H. TRIBE, AMERICAN CONSTITUTIONAL LAW 1465 (2nd ed. 1988); Linder, supra. Intermediate scrutiny is used when the interest involved is important but not fundamental. It applies to gender discrimination and cases of identity differentiation, for example, when illegitimate offspring are treated differently than legal offspring. See TRIBE, supra, at 1601-02, 1610-18; Linder, supra. Rational basis review generally favors a given governmental regulation because it is satisfied as long as there is any rational reason for such regulation. This is true even of regulations that treat people in a lesser-protected class unequally. See TRIBE, supra, at 1439-40, 1446-47; Linder, supra. Such a minimum level of scrutiny has been applied by the Court to homosexuals and children of illegal aliens and in socioeconomic regulation cases. See TRIBE, supra, at 1439-40; Linder, supra. In arguing that health care legislation that does not give the poor access to health care coverage would probably not pass muster even under a rational basis standard, I do not suggest that rational basis review should be employed to find a right to national health care. In fact, I believe strict scrutiny should be used to protect the poor from government regulations which discriminate against them, especially when it comes to health care. In this I am guided by Justice Stone, in United States v. Carolene Products, who held that strict scrutiny should be used to eradicate "prejudice against discrete and insular minorities . . . which tends... to curtail the operation of those . . . processes ordinarily to be relied upon to protect minorities." See TRIBE, supra at 1465 (citing United States v. Carolene Products, 304 U.S. 144, 153 n.4 (1938)). Certainly, the poor constitute a minority whose interests should be protected as much as other minority members like children and prisoners. I believe, however, that even a rational basis review would uphold national health care legislation for all Americans, including the poor in the face of comparably existing care for prisoners, for what rational basis is there for the government to provide health care to prisoners but not the poor? This question is compounded upon appreciation that the federal government provides health care to lowincome children through its national Children's Health Insurance Program (CHIP). See Children's Health Insurance Program (CHIP), NCSL: NATIONAL CONFERENCE OF STATE LEgislatures, http:// www.ncsl.org/issues-research/health/childrens-health-insurance- 
A second constitutional basis for national health care is the government's taxing and spending power, enumerated in Article $1, \S 8$, clause 1 , which states in part that "[t]he Congress shall have Power to lay and collect Taxes . . . to . . . provide for the ... general Welfare of the United States." The last part of this section gives Congress authority to "make all laws which shall be necessary and proper for carrying into Execution the foregoing Powers."55 When we appreciate that the individual clauses, together with the above provisos, grant Congress the power to do whatever it must to insure a common defense, ${ }^{56}$ regulate interstate commerce, ${ }^{57}$ enact requirements for citizenship, ${ }^{58}$ coin money, ${ }^{59}$ establish post offices, ${ }^{60}$ and declare war, ${ }^{61}$ it is obvious that health care is as much of a prerequisite to the "general welfare" of the United States as any of the above listed necessities are. ${ }^{62}$ Moreover, that health care is a

program-overview.aspx (last visited Oct. 19, 2012). The poor, like prisoners and children, do not have access to health care when left to their own ability to pay for it.

55 U.S. Const. art. $1, \S 8, \mathrm{cl} .18$.

56 Id. at cl. 1.

$57 \quad I d$. at cl. 3.

58 Id. at cl. 4.

$59 \quad$ Id. at cl. 5.

$60 \quad$ Id. at $\mathrm{cl} .7$.

61 Id. at cl. 11.

62 Many of the arguments that favor national health care are viewed as stemming from liberal, expansive readings of the Constitution. See generally Thomas Bodenheimer, The Political Divide in Health Care: A Liberal Perspective, 24 HEALTH AFF. 1426 (2005), available at http://content.healthaffairs.org/content/24/6/1426.full (stating that in the health care arena, many liberals feel that governments are the only institutions that can protect people's right to receive essential services including heath care). However, even an original intentionalist must acknowledge that the Framers, who did not know of private or national health coverage, would have demanded it, as they provided all the enumerated constitutional mandates of Article 1, Section 8, to further ensure the welfare and prosperity of American society. If anything, the Framers would have been more solicitous of universal health care than they were of the listed powers, for a polity that does not have its health needs met may very well prove unable, in any given instance, to engage in commerce, deliver the mail, or defend itself. In fact, at least one prominent conservative federal appellate jurist has denied that Original Intent renders the PPACA 
right, and not a privilege, inheres in the fact that the above enumerated powers, and the General Welfare Clause, are contained in the article which grants Congress taxation power. To be sure, if I as an American, have the right to a militia to protect me from invasion, a post office to deliver my mail, and a treasury to print money so I may engage in commerce, it follows that because I pay taxes, I have the right to have a portion of those taxes used to provide me with access to preventive health care to keep me well and to curative care should I get sick.

Another argument in favor of national health care is found in the tenor of the entire corpus of America's founding documents, including the Articles of Confederation, all parts of the Constitution, and the Declaration of Independence. To be sure, the totality of these writings bespeaks a desire on the part of America's founders to establish a government, under the rule of law, which would provide its citizens with opportunities conducive to their prosperity and well-being. ${ }^{63}$ Not only is this clear from the enumerated and unenumerated rights contained in the Constitution, it is obvious from language included in the Constitution and other documents that is not traditionally read to create rights. ${ }^{64}$ For example, although the Preamble to the

unconstitutional. See Paul, DC Circuit Upholds Healthcare Law and Demolishes Right's Arguments, PEOPLE FOR THE AMERICAN WAY (Nov. 8, 2011, 4:14 PM), http://blog.pfaw.org/content/dc-circuit-upholdshealthcare-law-and-demolishes-rights-arguments (noting that Judge Silberman does not agree that Original Intent renders the mandate that individuals purchase health insurance unconstitutional).

63 See e.g., ARTICLES OF CONFEDERATION of 1781, art. III ("The said States hereby severally enter into a firm league of friendship with each other, for their common defence . . . and their mutual and general welfare.") (emphasis added); DECLARATION OF INDEPENDENCE ("We hold these truths to be self-evident, that all men . . . are endowed . . . with certain unalienable Rights, that among these are Life, Liberty, and the pursuit of Happiness. - That to secure these rights, Governments are instituted among men.") (emphasis added); U.S. CONST., pmbl. ("We the People of the United States, in Order to form a more perfect Union ... insure domestic Tranquility . . promote the general Welfare ... do ordain and establish this Constitution.") (emphasis added).

64 See What are the Parts of the Constitution, LAWS.COM, $\mathrm{http}: / /$ constitution.laws.com/american-history/constitution/theconstitution (last visited Oct. 13, 2012) (stating that the Preamble was 
Constitution is said to have no legal authority, ${ }^{65}$ it does explain the "why" of the Constitution, namely, the six ends for which the Constitution was created. These goals are: (1) to form a more perfect union, (2) establish justice, (3) insure domestic tranquility, (4) provide for the common defense, (5) promote the general welfare, and (6) secure the blessings of liberty. ${ }^{66}$ It is inconceivable that Americans, who possess

the Founding Father's way of informing future generations of their motives and intent in writing the Constitution).

65 This seems to be the view of the Supreme Court. For example, see Jacobson v. Commw. of Mass., 197 U.S. 11, 22 (1905) (asserting that the Preamble has never been regarded as the source of any substantive power). However, the Court itself has opined that every word in the Constitution, which presumably includes the Preamble, must be given "due force" in interpreting what the document means. See Richfield Oil Corporation v. State Board of Equalization, 329 U.S. 69, 77-8 (1946) ("In expounding the Constitution of the United States, every word must have its due force, an appropriate meaning ... No word in the instrument, therefore, can be rejected as superfluous or unmeaning.") (citing Holmes v. Jennison, 39 U.S. 540, 570-71 (1840)). Moreover, President Monroe believed the Preamble should be considered key to understanding the Constitution. See Judicial Branch: Constitutional Role of the Judicial Branch, ENOTES http://www.enotes.com/judicialbranch-reference/ constitutional-role-judicial-branch (last visited Oct. 13, 2012) ("The introduction, like the preamble to a law, is the Key of the Constitution."). Moreover, some constitutional scholars believe the Preamble, and other founding documents, may be used to find constitutional norms. See generally Jack M. Balkan \& Sanford Levinson, Legal Historicism and Legal Academics: The Roles of Law Professors in the Wake of Bush v. Gore, 90 GEO. L.J. 173, 178 (2001) (noting the constitutional norms articulated in "thin Constitution" whose principles are outlined in the Declaration of Independence and the Preamble to the Constitution); A national health care that gives all Americans access to medical care would enable many more people to determine, and participate in, the progress of society. Finally, Professor Laurence Tribe, of Harvard Law School, believes the Preamble and Declaration are "important sources of authority" for finding a constitutional right to health care (Email from Laurence Tribe, Professor of Law at Harvard Law School, (Feb. 16, 2012, 19:30 EST) (on file with author)), and Professor Mark Brandon, of Vanderbilt Law School, is "committed to a position that encourages use of the Preamble in constitutional interpretation" (Email from Mark Brandon, Professor of Law at Vanderbilt Law School, (Mar. 22, 2012, 20:12 EST) (on file with author)).

66 See U.S. CONST. pmbl. 
constitutional rights to speak freely and assemble, ${ }^{67}$ have speedy and public trials, ${ }^{68}$ and vote, ${ }^{69}$ do not have a constitutional right to have their government provide them with health care. One final constitutional argument in favor of a right to national health care is twofold. First, the Framers of the Constitution fashioned the Ninth Amendment specifically to allow for the establishment of rights in the future that are not explicitly mentioned in the text of the Constitution. ${ }^{70}$ Second, because the Ninth Amendment fails to provide guidance on how to found unenumerated rights, it implicitly warrants that nontextual criteria, such as need, may be used to found such rights. ${ }^{71}$ To be sure, what could be a more compelling reason for a "new" right than because there is a need?72

67 See U.S. ConST. amend. I.

68 See U.S. CONST. amend. VI.

69 See U.S. CONST. amend. XV, XIX, \& XXVI.

70 See U.S. Const. amend. IX; Daniel A. Farber, ThE 'SILENT' NinTH AMENDMENT gIVES AMERICANS RIGHTS THEY DON'T KNOW THEY HAVE (2007).

71 The great jurist, Oliver Wendell Holmes, Jr., expressed this idea in different words when he stated famously in The Common Law that "The life of the law has not been logic: it has been experience." See Oliver W. HOLMES, JR., THE COMMON LAW (1881), available at http://constitution.org/cmt/owh/commonlaw.txt. By this, Holmes means that human "experience," i.e. our needs, or the things that shape our lives, and society in general, inform our laws, more than other factors. Id. ("The felt necessities of the time, the prevalent moral and political theories, intuitions of public policy ... have had a good deal more to do. . . in determining the rules by which men should be governed."). Holmes's opinion belongs to a school of legal thought called legal realism, which holds that more often than not, judges decide legal cases based not on rules, but on their intuitions, experiences, and prejudices, to find results which they feel are necessary in the face of given facts. See Bradley C. S. Watson, Oliver Wendell Holmes, Jr. and the Natural Law, NATURAL LAW, NATURAL RIGHTS AND AMERICAN CONSTITUTIONALISM, http://www.nlnrac. org/print/34 (last visited Oct. 13, 2012) ("[C]ourts adjudicate with an eye to law's practical effects."). For an excellent article about legal realism, see Kenneth E. Himma, Philosophy of Law, THE INTERNET ENCYCLOPEDIA OF PHILOSOPHY, http://www.iep.utm.edu/law-phil (last visited Oct. 19, 2012).

72 It may be the fact that national health care is debated at all, much less to the extent it is, proves that, to many individuals, health care is a necessity and not a luxury or even a commodity. To be sure, 
This latter point serves to rebut all those who deny there is a right to health care because such a right is not found in the Constitution. ${ }^{73}$ Now, how a right to health care should be implemented is something that, ultimately, must be established by the Legislature, in the same way it is for Congress to decide the means by which enumerated rights are enjoyed. However, because the Ninth Amendment acknowledges that an evolving society may find rights not mentioned in the text of the Constitution, the necessity of something that is required for the welfare of Americans can itself create a Constitutional Right. Now that the reasons why Americans possess a constitutional right to health care have been presented, below is a discussion on the different ways such a right may be implemented. ${ }^{74}$

were health care seen as a luxury, it would not be gist for intelligent debate. After all, we do not see serious people arguing about whether the poor should have access to luxury automobiles or iPhones. See Bodenheimer, supra note 62, at 1429 (stating that few would endorse the right of everyone to own a DVD player or drive a luxury car).

73 See David Meyers, Commerce Clause Jurisprudence and Original Intent in Health Care, JURIST (July 7, 2011), http://jurist.org/dateline/2011/07/david-meyers-commerce-clause.php

(last visited Oct. 19, 2012) (declaring that a national health care mandate is unconstitutional because the Commerce Clause has been interpreted way beyond what it actually states); Geoff B., You Do Not Have a 'Right' to Health Care, The MillenNIAL STAR (May 18, 2011), http://www.millennialstar.org/you-do-not-have-a-right-to-health-care (asserting that supposed rights to health care are not in the Constitution and were never intended to be); Health Insurance is Not a Right, People!, THE BoBo FILES (July 30, 2009), http:// thebobofiles.com/?p=1517 ("Nowhere in our constitution does it say that every individual in this country has the right to health care.").

74 For the sake of thoroughness I note another, albeit nonconstitution based, reason Americans are entitled to health care access. The United States provides financial assistance, not just to its own residents, but to the citizens of numerous foreign governments. Much such aid is not only to help such people, but for national security purposes, i.e. to protect Americans from their enemies. Yet, the actual amount of money we give to others is beyond unreasonable when one considers that, as a result, we cannot afford to cover all of our own people with adequate government-sponsored health care. Laurie Garrett, The U.S. promotes Universal Health Care, but only in Other Countries, http://www.theatlantic.com/international/archive/2012/06/ the-us-promotes-universal-health-care-but-only-in-other-countries/ 


\section{Ways to Provide Access to National Health CARE}

There are essentially three ways to implement national health care: single-payer health care, hybrid or two-tier health care, and private national health care. ${ }^{75}$ In singlepayer health care, the government pays for everyone's care from a fund set aside specifically for this purpose. ${ }^{76}$ With hybrid health care, health care is paid for through a combination of government and private sources. ${ }^{77}$ In national but private health care, individuals must fund their own care, but government resources are available to subsidize those who cannot entirely afford to do so. ${ }^{78}$

259160/ (last visited Jan. 31, 2013). Even buying into the view that health care for those who cannot afford it is charity, "charity begins at home," and the United States should take care of its own before it spends as much as it does to build up foreign societies. One major way the U. S. can help its own is to provide its residents with health care. The fact is that other countries, like Japan and Canada, spend less in both dollars and GDP percentage than we do on security so they can give their citizens health care, yet they appear to have more than enough resources to keep their borders secure and their citizens safe. Our government should learn from their example. See Talea Miller \& Larisa Epatko, Foreign Aid Facing Proposed Cuts and a Public Perception Problem, PBS NEWSHOUR (March 10, 2011), http://www.pbs.org/newshour/rundown/2011/03/foreign-aid-facingproposed-cuts-public-perception-problem.html (stating that in 2009, the U.S. spent 28.8 billion dollars and $.21 \%$ of its GDP, Japan spent 9.5 billion and $0.18 \%$ of its GDP, and Canada spent 4 billion and only $0.3 \%$ of its GDP, on foreign aid).

75 See Universal Health Care, QUICK OVERVIEw, http://www. quickoverview.com/issues/universal-healthcare-system.html (last visited Oct. 14, 2012).

76 See Single-Payer FAQ, Physicians FOR A NATIONAL HEALTH PROGRAM, http://www.pnhp.org/print/facts/single-payer-faq (last visited Oct. 10, 2012) [hereinafter PHYSICIANS FOR A NATIONAL HEALTH PROGRAM]; Universal Health Care, supra note 75 ("Single-payer health care is a system whereby one party, usually the government, pays for the health care of everyone.").

77 See Andrew Cohen, Spotlight: Berkeley CHEFS Promotes Hybrid Health Reform, BERKELEYLAW (Feb. 24, 2009), http:// www.law.berkeley.edu/3811.htm ("Hybrid health care describes universal coverage that combines elements of government-run programs and private-sector insurance plans.")

78 See Mandatory Health Insurance Requirement Begins in 2014, Individual Health Plans (Oct. 27, 2011, 1:27 PM), http://www. 
Although all such approaches have some merit, ${ }^{79}$ the best avenue by far that the United States should take to insure its people is a single-payer approach. This is for at least six reasons. First, unlike private insurance and even hybrid health care, all Americans regardless of income and assets would be covered for all medically necessary services, including physician visits and services, hospitalization, long-term care, dental needs, vision care, and prescription drug and medical supply costs. ${ }^{80}$ Such a plan is extremely necessary, because presently many government subsidized programs exclude many of the above services. ${ }^{81}$ Second, because a single-payer system will be funded and operated by a single entity, i.e. the government, it will cut down on

individual-health-plans.com/blog/mandatory-health-insurance

[hereinafter INDIVIDUAL HEALTH PLANS] (Starting in 2014, Americans must carry health insurance and the government may subsidize health insurance for those who make less than a certain amount.).

79 See Cohen, supra note 77 (A hybrid insurance plan "creates a new, publicly funded and administered health plan, gives the uninsured choice among alternative plans, and expands access to existing public insurance programs."); Universal Health Care, supra note 75 (noting that hybrid health care takes the burden of universal health coverage off the exclusive shoulders of the government, reconciles the competing interests of expanded access and rising costs, and negotiates a middle ground answer to whether universal health coverage is a personal or societal responsibility); Marissa Willman, What Are the Benefits of Private Health Care? EHow, http://www.ehow.com/print/facts_ 5030832_benefits-private-health-care.html (last visited Oct. 14, 2012) (private health care grants choice, ensures greater quality, eliminates waiting periods, and reduces government spending); Alan Nasser, Obama's Bad Case Against Single Payer: Solidarity vs. Individualism, COMMONDREAMS (Nov. 18, 2009), http://www.commondreams.org/ view/2009/11/18-5 (declaring that single-payer insurance has a majority of popular support, it detaches coverage from employment, makes national health care truly universal, and it promotes solidarity in both private and governmental vantage points).

80 See Physicians for a National Health Program, supra note 76.

81 See e.g., Individuals and Sole Proprietors: Benefit Package, HEALTHY NY, http://www.dfs.ny.gov/healthyny/hny_ind_sole_bp.htm (last visited Oct. 10, 2012) (Healthy New York, a New York State subsidized plan for low-income residents, that is provided by various insurance companies excludes "durable medical equipment" such as cpap machines used to treat sleep apnea and mental, vision, and dental care. 
the administrative costs that private and hybrid insurance plans require. ${ }^{82}$ Third, a single-payer plan will keep drug prices under control. This is because when patients are covered under one system, the payer, in this case the government, has more power to control costs than when multiple sources are responsible for providing drug care. To be sure, the unified source of their health care is a major reason drug prices in other countries are lower than they are in the U.S.83 Fourth, because single-payer plans would cover items that are not traditionally covered in many plans, and would probably not carry copayments or deductibles, ${ }^{84}$ they would provide coverage to the presently

82 See Physicians for a NAtional Health Program, supra note 76 ("The new costs to cover the uninsured under a single-payer system will be fully offset by administrative savings."); Mark Crane, US MD Administrative Costs 4 Times Higher Than in Ontario, Medscape Medical News (Aug. 3, 2011), http://www.medscape.com/viewarticle/ 747566 .

83 See Physicians for a NATIONAL HealTh Program, supra note 76 (stating that the clout that comes from having patients under one system is the reason single-payer country drug costs are lower than those in the U.S.); Tracy Staton, Europe Pays 40\% Less for Drugs Than U.S., FIERCE PHARMA (July 8, 2009), http://www.fiercepharma.com/ story/europe-pays-40-less-drugs-u-s/2009-07-08; Terry Campbell et al., Costs of Health Care Administration in the United States and Canada, 349 NEw ENG. J. MED. 768 (2003), available at http://www.nejm.org/ doi/full/10.1056/NEJMsa022033 (emphasizing that the gap between the U.S. and Canada in health care expenditures might be reduced if administrative costs in the U.S. were trimmed through the adoption of a Canadian-style health care system).

84 The question of what purpose copayments and deductibles serve is an interesting one. Insurance companies claim they reduce the cost of health care. See What is a Copay?, INSURANCE PROvIDERS, http://www.insuranceproviders.com/what-is-a-copay (last visited Oct. 10, 2012) (explaining that paying higher copays saves consumers money on premiums). Others suggest co-payments motivate patients to take their medical care more seriously. See Ilyne Sandas \& Christine Siegel, Managing Managed Care Plans: Co-Pays, NETPLACES, http://www. netplaces.com/parenting-kids-with-anxiety/managing-managed-careplans/co-pays.htm (last visited Oct. 10, 2012) (arguing that making a financial contribution at the time of service may increase patient motivation and follow-through). The fact remains, however, that those with high copayments and deductibles frequently do not receive the care they need or do not benefit from such care as often as they would if they were not burdened with copays and deductibles. See Rhonda Day, 
underinsured as well as the uninsured. ${ }^{85}$ This is vital because as recently as $2009,62 \%$ of U.S. bankruptcies were due to medical expenses and $80 \%$ of those bankruptcies were filed by people who had health insurance. ${ }^{86}$ Fifth, a national single-payer health plan will keep overall health care costs down by de-commercializing health care and limiting for-profit involvement in how health care is delivered. 87 It would accomplish this in three ways. First, the payer (the government) would not spend more on medical technology than is needed to provide health care. ${ }^{88}$ Second, because a single-payer system would be delivered by the government, it would eliminate the excessive executive compensation packages in vogue at private insurance companies. ${ }^{89}$ Third, it would block the often

White House Issues New Rules to Eliminate Copays and Deductibles for Preventive Screenings and Tests, EXAMINER.COM (July 15, 2010), http://www.examiner.com/article/white-house-issues-new-rules-toeliminate-copays-and-deductibles-for-preventive-screenings-and-tests (explaining that access to health services often limited by copayments, deductibles, and other financial burdens). Those with high copayments and deductibles also do not comply as well with their need to take medicine. See Martin Sipkoff, Lowering Copayments Can Improve Quality of Chronic Disease Care, Managed Care (July 2007), http://www.managedcaremag.com/archives/0707/0707.medmgmt.html (noting that one Aetna client is convinced that lowering or eliminating copayments will increase compliance).

85 See Physicians for a NAtional HEALth Program, supra note 76 (declaring that the most effective system to combat an epidemic of underinsurance is a single-payer one).

86 See Meg White, 25 Million Underinsured Americans Might as Well Be on the Moon' for Their Access to Medical Treatment, BuzzFLAsH (Oct. 16, 2009), http://www.truth-out.org/buzzflash/commentary/item/ 8125-25-million-underinsured-americans-might-as-well-be-on-the-moonfor-their-access-to-medical-treatment (explaining that $80 \%$ of the $62 \%$ of bankruptcies due to medical care are filed by the underinsured).

87 See PHYSICIANS FOR A NATIONAL HEALTH PROGRAM, supra note 76 (stating that the keys to savings lie in limitations on for profit involvement in health care delivery).

$88 I d$. (arguing that health planning to assure that investments in expensive new technology meet needs but do not exceed them is the only proven means to limit excessive and dangerous interventions that drive up costs).

$89 \quad I d$. (noting that limits on excessive compensation of health care executives are needed). 
enormous costs insurance companies spend to influence the public that private health insurance is the preferred manner in which they should obtain their health insurance. ${ }^{90}$ Finally, because a single-payer plan would be operated by the government, all medical data, including patient and hospital records, could be housed in one central computerized repository. ${ }^{91}$ This would further keep administrative costs down, discourage doctors from fraudulently billing for unperformed procedures, ${ }^{92}$ and make it much easier to coordinate patient health data between physicians and hospitals in the event a patient changes doctors or moves to another locale. ${ }^{93}$

\section{ARguments Against National Single-Payer Health CARE}

In spite of these reasons in favor of national single-payer health care, many individuals, in the medical profession and without, raise seemingly cogent arguments against such a system. Although it is impossible to visit all such objections in this paper, I examine some important ones. First, there is a worry that if the government controls health care, it will take control over patient care away from patients and their doctors. ${ }^{94}$ However, because a single-payer program

90 See Sudbury (MA) DEmocratic TOWn CommitTee, SinglePayer Universal Health CARE: AN IdeA Whose Time Has Come 4-5 (2009), available at http://www.sudburydemocrats.org/pdf_files/ Single_Payer.pdf [hereinafter SUDBURY (MA) DEMOCRATIC TOWN COMMITTEE](declaring that pharmaceutical and insurance companies spend a significant amount of money cultivating influence).

91 See Kao-Ping Chua, Single Payer 101, AMERICAN MEDICAL STUDENT ASSOCIATION, http://www.amsa.org/amsa/Libraries/ Committee_Docs/SinglePayer101.sflb.ashx

92 See Arnold Relman, In Dire Health, THE AMERICAN PROsPECT (Jan. 13, 2012), available at http://prospect.org/article/dire-health (arguing that in a single-payer system there would be no bills and little or no fraudulent billing); See Kao, supra Note 91.

93 See Gordon Schiff and the PNHP Working Group on Quality, How Single-Payer Health System Reform Improves Quality, http://www. pnhp.org/facts/quality.pdf.

94 Physicians fOR a National Health Program, supra note 76, ("There is a myth that with national health insurance the government will make the medical decisions."). 
would be run by the government, it would be public, and therefore the public would have a say in how it is run and patients and doctors would remain in control of health care. ${ }^{95}$

Second, it is feared that under a single-payer program, physicians' salaries and fees will go down which could cause qualified individuals to choose other professions to go into, and exceptional ones to quit the profession. ${ }^{96}$ Although it is true that many American physicians are leaving medicine to pursue other careers, 97 this is more often due to frustration with having to deal with HMOs than with dissatisfaction with the medical profession. ${ }^{98}$ Third, it is objected that adapting a single-payer national health care system will unfairly eliminate most of the present insurance industry's administrative workers. ${ }^{99}$ Although it is true that many who work for HMOs and other private insurance companies will need to be placed in other positions and possibly other professions, this is not a valid reason to reject

95 See Frequently Asked Questions About Single Payer Health Insurance, TEXANS FOR A NATIONAL HEALTH PROGRAM, http://www.healthcareforalltexas.org/FAQs.pdf (last visited Oct. 10, 2012) (In a publicly-financed universal health care system medical decisions are left to patient and doctor.); PHYSICIANS FOR A NATIONAL HEALTH PROGRAM, supra note 76 (In a publicly-financed universal health care system, medical decisions are left to the patient and doctor.).

96 See Physicians for a National Health Program, supra note 76.

97 See Valerie M. Harrison, Being a Doctor, Pros, Cons and What It's Really Like. The Process of Becoming a Doctor, MOMMD, http://www.mommd.com/beingadoctor.shtml (last visited Oct. 19, 2012) (Many good doctors are leaving the profession.).

98 See Kevin Pho, Why Pediatricians and Other Primary Care Doctors Leave Medicine, MEDPAGETODAY's KEVINMD.COM, http://www.kevinmd.com/blog/2010/06/pediatricians-primary-caredoctors-leave-medicine.html (last visited Oct. 10, 2012) (explaining examples of frustrations doctors have dealing with HMOs); $Q \& A$ : Maggie Kozel on Leaving Medicine, Chelsea Green Publishing (Feb. 24, 2011, 8:55 AM), http://www.chelseagreen.com/content/qa-maggie-kozelon-leaving-medicine (explaining that the frustration of dealing with HMOs caused pediatrician to quit medicine).

99 See Physicians for a National Health Program, supra note 76. 
a more cogent and fair health care program. ${ }^{100}$ Moreover, a single-payer protocol would still need a healthy cadre of administrative employees, and many who currently work for HMOs and other private insurance companies can easily be retrained to handle claims and other duties under a national insurance program. ${ }^{101}$

Fourth, it is argued that a competitive, private, free market approach to health care would streamline health care costs to make them more cost effective. ${ }^{102}$ However, it is precisely the competition between insurance companies in the private sector that has caused the costs of health insurance to spiral out of control and become unaffordable for so many. ${ }^{103}$ A single-payer plan, by providing health care to all Americans regardless of their ability to pay, would keep health care costs down particularly because such a program will not need to spend small fortunes on advertising, consumer influence, and the administrative costs associated with these realities. ${ }^{104}$ The lack of competition as a cost-controlling mechanism would apply to hospitals as well as private insurance companies. ${ }^{105}$

100 After all, did society refrain from embracing the automobile because doing so put innumerable horse-and-buggy drivers out of work?

101 See PHYSICIANS FOR A NATIONAL HEALTH PROGRAM, supra note 76 (stating that the new system will still need some people to administer claims and work in long-term care facilities and nursing homes).

102 See id. ("Competition will streamline the costs of health care and make it more efficient.").

103 See id. (noting that past competition in private health care is the major cause of rising costs); see also Angry Bear, The Return of the Myth that Competition will Fix Medicare, BUSINESS INSIDER (Apr. 5, 2011), http://articles.businessinsider.com/2011-04-05/markets/29991557 _1_health-insurance ("Health insurance premiums for workers in large companies . . . covered by private, competitive, employer-sponsored health insurance plans -- rose over $135 \%$ over the ten year period 1999 and 2009.") (emphasis in original).

104 See SUDBURY (MA) DEMOCRATIC TOWN COMMITTEE, supra note 90 at 3, 4-5 (noting the "extraordinary and wasteful insurance company advertising costs" and that insurance companies "spend a significant amount to cultivate influence").

105 See Physicians FOR A NATIONAL HEALTh PROGRAM, supra note 76 (noting that hospital competition "drives up overall medical costs" and "waste[s] money on advertising and marketing"). 
Another objection to single-payer insurance is that it would eliminate, reduce, or hamper medical research. ${ }^{106}$ However, already this does not appear to be the case because much, if not most, research in this country is financed by the National Institutes of Health (NIH), ${ }^{107}$ a government agency that has innovated many medical treatments and cures. ${ }^{108}$ Moreover, many medical discoveries and treatments we take for granted today were discovered in countries that operate under national health care systems. ${ }^{109}$ For example, the CT-scan was invented in England, and much of how we understand the genetic basis of Alzheimer's disease was gleaned from research conducted in France and England. ${ }^{110}$

Another argument against government-sponsored health care programs is that they will raise taxes. ${ }^{111}$ Although it is

106 See David Hogberg, The Myths of Single-Payer Health Care, FREE MARKET CURE, http://freemarketcure.com/singlepayermyths.php (last visited Oct. 12, 2012) ("While it is true that medical research will not 'disappear,' it will surely decline."); see also Trisha Torrey, The Role of Medical Research in Healthcare Reform: the Ripple Effect of Conflicts of Interest and Money Allocations on Patients, ABOUT.COM (Oct. 26, 2011) http://patients.about.com/od/healthcarereform/a/Reform-research. $\mathrm{htm}$ (noting that less money is available for research by government sources and insurance companies and that private enterprise have become major funders of research).

107 See PHYSicians FOR A NATIONAL HEALTH PROGRAM, supra note 76 ("Much current research is funded through the National Institutes of Health.").

108 See Turning Discovery into Health, NIH, http://www.nih.gov/ about/impact/impact_health.pdf (last visited Oct. 13, 2012) (noting that NIH-funded research is tied to $60 \%$ lower death rate for coronary artery disease, the increased survival rates for various forms of cancer, and the development of vaccinations).

109 Myths-Overview, HeALTH CARE FOR ALL-TEXAS, http://www. healthcareforalltexas.org/Myths.html (last visited Oct. 13, 2012) [hereinafter HEALTH CARE FOR ALL - TEXAS] ("Many [medical] discoveries have been made in countries that have national health care systems ....").

110 See id.

111 See Peter Grier, Health Care Reform Bill 101: Who Will Pay for Reform?, CHRISTIAN SCI. MONITOR (Mar. 21, 2010), http://www. csmonitor.com/USA/Politics/2010/0321/Health-care-reform-bill-101Who-will-pay-for-reform (noting that some of the $\$ 940$ billion required to pay health care reform over ten years will come from new taxes). 
true that any form of national health care will need to be realized through higher taxes, this fact in itself should not be fatal to national health care. First, such taxation, which can be levied uniformly and fairly based on income, may very well prove to be preferable, and ultimately less expensive, than the insurance premiums, copayments, deductibles, that many Americans are burdened with. ${ }^{112}$ Furthermore, it is through taxation that Americans fund police and sanitation departments, public education, the military, and social security, institutions that most, if not all, Americans agree are of vital importance to society. ${ }^{113}$ Moreover, through their taxes, Americans are already paying for the health care of the uninsured.114 Raising taxes to pay for a national health care program would simply streamline this reality and make it more equitable for all Americans by using the taxes of each American to pay for everyone's health care. Finally, because national health care is a right that all Americans, regardless of income, should enjoy, it may be considered a public necessity in the same manner as access to police protection, sanitation, public education, and bridges and parks, is. Seen in this light, there should be no more objection to using taxation to pay for national health care than there is for any other societal benefit. Having examined the history of health care, whether national health care is a right, how it should be implemented, and some of the arguments against it, I now look to ways in which national health care can be funded.

112 See HEALTh CARE FOR ALL - TEXAS, supra note 109 ("All new taxes would take the place of current insurance premiums, co-pays, deductibles and any and all other out of pocket payments.").

113 See Policy Basics: Where Do Our State Tax Dollars Go?, CTR. ON BUDGET AND POL'Y PRIORITIES, http://www.cbpp.org/files/policybasicsstatetaxdollars.pdf (last visited Oct. 19, 2012) (noting that state tax dollars are spent on education, police, help for the poor, corrections and other essential state services); see also How Your Tax Dollars Are Spent, CNBC.COM, http://www.cnbc.com/id/26941466/?slide=1 (last visited Oct. 13, 2012).

114 See AETNA, supra note 3. 


\section{How a National Health Care Program Should be FUNDED}

There are three ways to fund national health care plans. All of them involve using taxpayers' dollars. The only difference between them is the degree of direct taxpayer involvement and whether the government will be exclusively or partially responsible for the costs of such care. For example, a national health care system can be realized by Americans paying government health care premiums out of pocket. The amount of such premiums would depend on income. Those who earn more would pay more and naturally, those who earn less would pay less. Americans whose income is below a certain level would be exempt from such premiums; their care would be paid for entirely by the government. ${ }^{115}$ Other ways national health care can be paid for are deducting the cost of one's annual health care from her paycheck, paying upfront for services and being reimbursed by the government, ${ }^{116}$ and permitting health consumers to deduct the value of all their health expenditures on their tax returns. ${ }^{117}$ The self-employed would pay government subsidized premiums, and lowincome individuals would be covered completely and upfront by the government.

115 See Premium and Cost-Sharing Subsidies in the Affordable Care Act, COMMUNITYCATALYST.ORG (Sept. 2010), http://www. communitycatalyst.org/doc_store/publications/Affordability_in_ACA.pdf (noting that tax credits starting in 2014 will lower the costs of premiums and providing tables that show premiums are based on income levels); see also INDIVIDUAL HEALTH PLANS, supra note 78 ("The less money you make, the more your health coverage will be subsidized.").

116 See Steve Gold, How European Nations Run National Health Services, THE GUARDIAN (U.K.) (May 11, 2011), http://www.guardian. co.uk/healthcare-network/2011/may/11/european-healthcare-servicesbelgium-france-germany-sweden (noting that German citizens pay into one of three hundred sickness funds through their payroll or bank and that French citizens are immediately reimbursed by the government for doctor visits they pay for).

117 See William Perez, Deducting Health Insurance, ABOUT.COM (Mar. 15, 2011), http://taxes.about.com/b/2011/03/16/\%20deductinghealth-insurance.htm (noting that Americans can deduct the cost of health insurance on their income tax returns). 
Finally, as we have seen, a government sponsored national health care plan can be funded by taxpayer contributions and delivered by the government via a singlepayer system without any upfront expenditures and reimbursements or payroll deductions. This is the most cogent manner national health care should be implemented for at least three reasons. First, it would be truly "national" inasmuch as it would cover all Americans without regard to income. Second, it would exponentially cut down on administrative costs and bureaucratic involvement because, unlike the German and French systems, there would not be as much of a need to keep track of what or when residents have paid for health care or deal with the extra paperwork involved to repay nationals for their lay-outs in a timely fashion. However, under a single-payer system there will still be a need for paperwork or record keeping, as some governmental patient health care tracking would be required.118 Also, record keeping promotes four important values. First, to ensure that patients are not over treated. Second, it combats fraud. Third, it ensures that doctors, hospitals, and other health care workers are appropriately compensated. Fourth, it helps to protect doctors from illegitimate malpractice suits. Third, any health care program that allows the government to pay health costs without out-of-pocket, upfront payments, will psychologically reinforce the idea that government health care is something all Americans are entitled to by right. ${ }^{119}$

We have examined historical, constitutional, and pragmatic aspects of national health care. We now visit two philosophical issues that pertain to all governmentsponsored health plans. First, I examine the perceived injustice of requiring more affluent and healthy Americans to contribute through their tax dollars to the health care of the unhealthy and less affluent. Second, I examine the inherent tension between the political philosophy of a

118 See Medical Record Keeping for Health Care Providers, nursinglink.monster.com/training/articles/352-medical-record-xe (last visited Jan. 31, 2013).

119 See Kao, Supra Note 91. 
national health care program, which is socialist, in a capitalist country like the United States.

\section{PHILOSOPHICAL ISSUES AND QUESTIONS OF FAIRNESS Over National HEALTH CARE}

An issue that crops up repeatedly regarding national health care plans is the seeming unfairness of requiring more affluent and healthy individuals to pay, indirectly through taxation, for the health needs of the less affluent and less healthy in society. ${ }^{120}$ This objection is often compounded and complemented by the realization that many Americans bring disease onto themselves through lack of exercise and unhealthy food choices. ${ }^{121}$ Although there is truth to this complaint, when health care is seen as a right, it loses much of its bite. This is because there are numerous other areas of American life, from police protection and sanitation benefits, to public school education and military operations, which are supported by the tax dollars of Americans who live in affluent and clean neighborhoods that may not need as much police

120 See Things Considered, Arguments Against Universal Healthcare in America, HuBPAGES.COM, http://thingsconsidered. hubpages.com/hub/Arguments-Against-Universal-Healthcare-in-

America (last visited Oct. 13, 2012) (discussing why healthy people should have to pay for unhealthy people); see also Geoff B., supra note 73 (noting there is no right to health care under the principles of natural law); see also Claire Andre et al., Voluntary Health Risks: Who Should Pay?, SANTA Clara UNIVERSITY, http://www.scu.edu/ethics/

publications/iie/v6n1/voluntary.html (last visited Oct. 13, 2012) (proposing that people should pay for their own health risks).

121 See Joe Messerli, Should the Government Provide Free Universal Health Care for All Americans? BALANCEDPOLITICS.ORG, http://www.balancedpolitics.org/universal_health_care.htm (last visited Oct. 13, 2012) (noting that universal health care means the costs will be spread to all Americans, regardless of health or medical need, which is fundamentally unfair because it punishes those who take care of themselves and rewards those who do not); see also Shereen Jegtvig, Americans Are Not Living a Healthy Lifestyle, АBouT.com (Jul. 6, 2012), http://nutrition.about.com/od/researchstudies/a/unhealthy_ams. htm (noting an unhealthy lifestyle means more illnesses, more individual health expenses, and more of a burden on the healthcare system). 
surveillance, or clean-up, as poorer, crime-ridden locales do, or who may not agree with all details of foreign policy expenditures. The fact is that just as police protection, sanitation benefits, educational resources, and a strong military presence are necessary if society is to function at a high level free from crime, garbage borne diseases, illiteracy, and threats from abroad, national health care is required to keep as many members of society healthy and therefore presumably productive, as possible.

The question of why society should pay to cover the health care expenses of those who have not made healthier lifestyle choices, may be answered via a two-pronged approach, both of which require not merely compassion, but a healthy dose of realism. First, I again look to those services that most Americans do not mind paying for to point out that many of them are necessary due to both the ill behavior of at least some members of society, as well as the impracticality of requiring individuals who are generally ill-equipped to effectively manage various facets of their lives, to teach themselves. For example, police are needed largely because people do not always act legally or peacefully. Public schools are needed, not just for the children of less affluent parents who cannot afford to send them to private or parochial schools, but for students whose parents are themselves illiterate, alcoholic, emotionally or developmentally disabled, or otherwise incapable of educating them. If this is true in these and other areas in which people are challenged and incapable, due to either irresponsibility or innate deficiency, why should it not be true in regards to the bad choices whole segments of our society make when it comes to life style? In fact, all of society will lose out, in lost productivity, prosperity, and contribution, if our government does not encourage us, through national health care, to provide health insurance for those who are less healthy than others, even if such compromised health status was caused by personal irresponsibility and neglect.

The second prong of this response is that the seeming legitimacy of the question it addresses is predicated on a sense of moral superiority that is both unfortunate and 
often non-warranted. The fact is that most of us do not always do what we are supposed to, either willfully or by accident. Although I am just as guilty of such misfeasance as the next person (I did not reach my present weight of 330 lbs. by eating apples and yogurt), I find it less than easy to entirely appreciate a cogent distinction between socially supportive measures many of us do not seem to mind funding, like prisons for criminals, and free contraception for the sexually irresponsible and health care for all Americans, including those who are sick because of wrong choices, which care many seem to disapprove of. To be sure, there are appreciable distinctions between these examples. For example, prisoners are incarcerated to punish them for past misconduct and condoms are given to high school students to prevent them from producing unwanted children whom the government would have to support. In both such instances, however, individuals receive benefits that, due to their situation and or economic capabilities, they cannot pay for on their own.

However, the basic philosophy underlying them is the same. Namely, fellow human beings are in trouble and need the help, guidance, and support of others. ${ }^{122}$

The second problem many Americans have with national health care is the fact that aspects of it are socialistic. ${ }^{123}$ To

122 A fact that tends to be overlooked in health care discussions that center on objections to paying for those who are unhealthy due to bad lifestyle choices, is that such aid is designed to not contribute to sickness. To be sure, many government food programs pay for basic healthy food staples, but not deleterious items like cigarettes. See Supplemental Nutrition Assistance Program, Eligible Food Items, USDA, http://www.fns.usda.gov/snap/retailers/eligible.htm (last visited Oct. 14, 2012) (showing that the supplemental nutrition assistance program may be used to purchase breads, fruits, vegetables and meat, but may not be used for alcohol or tobacco). In the same vein, government-sponsored health care, regardless of the form it takes, should encourage healthier lifestyle changes by charging so-called "sin taxes" on unhealthy items, and/or providing tax deductions, or other "rewards" to those who adopt healthier lifestyles. Doing so would take a large bite out of the unhappiness many healthier Americans will feel paying for insurance for those who are not as well.

123 See Michael F. Cannon, Does Barack Obama Support Socialized Medicine?, CATO INSTITUTE (2008), http://www.cato.org/pubs/bp/ 
be sure, few things arouse the ire of dedicated, loyal, and patriotic Americans as easily as the implication that something is not capitalistic, never mind socialistic. This is especially true when the government is involved. We should be mindful of a few facts, however, before we address this question. First, there is a difference between socialism and communism.124 Second, socialism and 'socialized medicine' are not the same thing. ${ }^{125}$ Third, although communism and capitalism are incompatible governmental systems, socialism and capitalism may be compatible and socialism and democracy are certainly compatible. ${ }^{126}$ Finally, the very notion of "rights" across a broad and

bp108.pdf (describing the many critics that prefer to label President Obama's health care plan "socialized medicine"); see also Paul Steinhauser, Giuliani Attacks Democratic Health Plans as Socialist, CNN.COM (Jul. 31, 2007), http://articles.cnn.com/2007-07-31/politics/ giuliani.democrats_1_health-care-private-health-insurance-frontrunnerin-national-polls?_s=pm:POLITICS (stating that the Democrats' proposal is un-American and socialist); see also Lawrence R. Huntoon, Universal Health Coverage-Call It Socialized Medicine, 5 MED. SENTINEL 134 (2000), available at http://www.jpands.org/hacienda/ article49.html (noting the distinction between universal coverage and the delivery and practice of medicine).

124 Socialism \& Communism Explained, Socialism Vs. CoMmUnism, http://www.socialismvscommunism.org (last visited Oct. 14, 2012) (noting that socialism advocates a system of collective or government control and management of the means of production and distribution of goods whereas communism aims to eliminate private property ownership so all property may be controlled by the government and thereby remove class distinctions).

125 See Paul Stepansky, "Socialized Medicine," Anyone?, MEDICINE, HEALTH AND HISTORY (Jan. 24, 2012), http://adoseofhistory.com/2012/01/ 24 /socialized-medicine-anyone (discussing the confusion over the terms "socialized medicine" and "socialism"); see also Robert Laws, Does Having Socialized Medicine Make a Country Socialist?, HeLIUM (Oct. $22, \quad 2009), \quad$ www.helium.com/items/1624475-does-having-socializedmedicine-make-a-country-socialist (noting that the adoption of a socialized medical system does not make a country socialist).

126 See Soclalism VS. CommUNiSM, supra note 124 (noting that unlike communism, socialism can possibly exist with capitalism); see also Woodrow Wilson, Socialism and Democracy, TEACHINGAMERICANHISTORY.ORG, http://teachingamericanhistory.org/ library/index.asp?document=2208 (last visited Oct. 13, 2012) (noting that, in theory, socialism and democracy are compatible). 
diverse nation-wide landscape necessitates some amount of socialism, which is already practiced in the United States.

To begin, although many opponents of national health care programs phrase their objections in terms of "socialized medicine," their arguments would carry more impact if they inveighed against "communistic medicine." This is because it is truly communism, and not socialism, at least limited to the matter of health care, that they seem to be protesting. ${ }^{127}$ To appreciate this, and make it easier to see why national health care is not nearly the threat its opponents would have us believe it is, realize that although both communism and socialism both cede power to the government, communism does this across the board, in all areas of social intercourse while socialism limits government control to wealth distribution and the funding of societal necessities. ${ }^{128}$ Understood this way, even if national health care is viewed as a form of "socialized medicine," 129 it will not be that much of a threat to our way of life. This is partially because socialized medicine, like other manifestations of socialism, is compatible with a capitalist society like the United States. ${ }^{130}$

The reason socialized medicine is compatible with capitalism is because a government-funded and executed health care program, like other socialized entitlements (such as police, sanitation, education, etc.), does not prevent Americans from competing in a capitalistic, free-market environment to provide luxuries and a better standard of living for themselves in other areas that affect them. For example, even with government-guaranteed health coverage, Americans will still need to compete in a capitalist marketplace to obtain more spacious homes, more expensive

127 See Socialized Medicine, CONSERVAPEDIA, http://www. conservapedia.com/Socialized_medicine (last visited Oct. 14, 2012) (noting that President Reagan's opinion was that socialized medicine will completely erode the freedoms of both patients and doctors).

128 See SOCIALISM VS. COMMUNISM, supra note 124.

129 See PHYSICIANS FOR A NATIONAL HEALTh PROGRAM, supra note 76 (noting that socialized medicine is a system in which doctors and hospitals work for and are paid by the government).

130 See SocIALISM VS. COMMUNISM, supra note 124 ("Unlike communism, socialism can exist with capitalism . . .."). 
cars and clothes, better vacations, etc. This reality takes the lie out of the misconception that capitalism is preferable to any amount of socialism because socialism, like communism, will chill incentives individuals have to work harder and be more productive.131 In fact, a "modified capitalism" which, as a result of the socialized benefits Americans already enjoy is the norm in present day America, may actually provide us with greater incentives to work and be productive. This is because, unlike members of a entirely capitalist society whose labor dollars must go to meet more of their basic needs, workers in a modified capitalist society that is paying more of those needs have that much more income at their disposal to fund a higher standard of living for themselves and their families. The awareness that their labor is helping to finance their dreams and goals, and not merely paying for essentials or increasing their employers' wealth, may motivate workers in a modified capitalistic environment to be more industrious.

Finally, to further render the idea of governmentsponsored health care more palatable to a greater number of people, we should differentiate between a "right to health" and a "right to health care." The two are not synonymous. It may be that many Americans are opposed to national health care because they mistakenly believe this requires them to support a right to health. ${ }^{132}$ However, proponents of national health care actually mean there is a right to health care and not a right to health, because only

131 See Mark J. Perry, Why Socialism Failed, 45 THE FREEMAN 363 (1995) (noting that socialism is based on a theory that incentives don't matter); see also Todd Ganos, Why Socialism Doesn't Work, FORBES.COM (Feb. 17, 2012), http://www.forbes.com/sites/toddganos/2012/02/17/why-socialism-doesntwork (noting that the socialist model removes incentives to excel).

132 Module 14: The Right to Health, UNIVERSITY of MinNESOTA HUMAN RIGHTS LIBRARY, http://www1.umn.edu/humanrts/edumat/ IHRIP/circle/modules/module14.htm (last visited Oct. 14, 2012); see also Health and Human Rights, WORLD HEALTH ORGANIZATION, www.who.int/hhr/en (statement of Dr. Margaret Chan) ("The world needs a global health guardian ... and a defender of health, including the right to health."). 
God or nature, and to some extent, one's own efforts, can assure the state of an individual's health. ${ }^{133}$ In fact, because so many variables including food, exercise, genetics, and luck go into determining the state of one's health, it would be absurd to speak of a "right to health." This is equally true of all other areas in which the government provides national assistance to meet the needs of its residents. For example, although the government cannot guarantee that individual Americans will be safe at all times and in all locales, we, because we pay taxes, have a right to being protected by a militia. ${ }^{134}$ We do not have a right to safety. Because the trajectory from idiocy to genius allows for too much of a variable in the intelligence levels of individuals, Americans do not possess a right to be smart. Children have a right to education. ${ }^{135}$ This distinction is essential because a mistake in what any given right means and entails not only confuses the issue in the instant case of national health care, but obfuscates important reasons we have rights in the first place, namely the utilitarian basis of rights and society's duty to take care of those who cannot take care of themselves. ${ }^{136}$ For example, there may be occasions in which the greatest good for the most people requires that society not favor the greatest number, as when society must protect a minority from the tyranny of the majority. ${ }^{137}$

133 See Eduardo Gomez, In Brazil, Healthcare is a Right, http://www.cnn.com/2012/07/13/opinion/gomez-brazil-healthcare/index. html?iref=allsearch (last visited Jan. 31, 2013).

134 U.S. CONST. amend. II.

135 See Federal Agencies Remind Public Schools All Children Have Right To Public Education Regardless Of Immigration Status, http://www.aclu.org/immigrants-rights/federal-agencies-remind-publicschools-all-children-have-right-public-education-re (Last visited Jan. 31, 2013).

136 See Peter Wehner, The Responsibility of Government, http://www.commentarymagazine.com/2012/06/18/the-responsibility-ofgovernment-and-disadvantaged/\#more-797147 (last visited Jan. 31, 2013).

137 See Direct Democracy: The Tyranny of the Majority, THE ECONOMIST, (Dec. 17, 2009), available at http://www.economist.com./ node/15127600 (describing how the tyranny of the majority in direct democracies can adversely impact the rights of minority groups); see 
Utilitarianism, as a political doctrine, was first advanced in modern times by Jeremy Bentham, a British subject, in the same year America won its revolution. In A Fragment on Government, Bentham writes that "[i]t is the greatest happiness of the greatest number that is the measure of right and wrong." 138 John Stuart Mill then refined Jeremy Bentham's thesis by adding the concept of consequentialism to it. 139 Under consequential utilitarianism, the happiness of the greatest number of persons is not sufficient to render an action, or course of action, correct. To qualify as correct, a course of action must result in foreseeable consequences that provide the greatest good to the greatest number of persons. ${ }^{140}$ John Stuart Mill's expansion of Jeremy Bentham's utilitarianism then led to a communitarian liberalism, which in turn led to social democracy under which, if individuals cannot supply the means to fund their basic needs, the government must fund those needs for them. ${ }^{141}$ Social democracy has served as the political theory behind many of America's most relied on public welfare institutions, including those of the so-called "Great Society."142

generally THE FEDERALIST No. 10, (James Madison) (discussing the tyranny of the majority).

138 JEREMY BENTHAM, A FRAGMENT ON GOVERNMENT AND INTRODUCTION TO THE PRINCIPLES OF MORALS AND LEGISLATION 3 (Wilfrid Harrison ed., Oxford Press 1967) (1776) (emphasis omitted).

139 JOHN STUART MILL, UTILITARIANISM 263 (Mary Warnock ed., World Publishing Company 1971) (1863) (noting in chapter two that actions are right in the proportion they tend to promote happiness and are "secured to all mankind"), available at www.utilitarianism.com/mill2.htm.

140 See Philip A. Pecorino, Ethics -Utilitarianism, http://www. qcc.cuny.edu/socialsciences/ppecorino/MEDICAL_ETHICS_TEXT/Chapt er_2_Ethical_Traditions/Utilitarianism.htm (last visited Jan. 31, 2013);

141 See Bodenheimer, supra note 62, at 1426-27 (noting that after Mill introduced the ideal communitarian utilitarianism, liberal principles shifted to a government that was responsible to provide the greatest happiness and welfare for the greatest number of people).

142 See Joseph A. Califano Jr., What Was Really Great About the Great Society, WASH. MONTHLY (Oct. 1999), available at www.washingtonmonthly.com/features/1999/9910.califano.html (noting that the efforts of the Great Society included Head Start, Medicare and Medicaid programs, and civil rights, clean air and water acts). 
National health care may be said, therefore, to be both overtly and implicitly mandated by the Constitution, and other founding documents of the United States, and sanctioned by numerous political and philosophical theories. Also, it does not violate the democratic or capitalistic foundations this country was built on. Likewise, the idea of a universal, government-funded and realized health care program is also understood to be a fundamental right by organizations, associations, and thinkers who are not limited either by American political or constitutional thought, or a particular political philosophy.

To begin, the Universal Declaration of Human Rights states that "[e]veryone has the right to . . . medical care," ${ }^{143}$ and the International Covenant on Economic, Social and Cultural Rights requires, "[t]he creation of conditions which would assure to all medical service and medical attention in the event of sickness."144

Many scholars also believe, premised on legal, political, philosophical, and moral grounds, that health care is a human right that must be made available to all, irrespective of an individual's ability to pay for it. ${ }^{145}$ Three examples of

143 The Universal Declaration of Human Rights, G.A. Res. 217 (III) A, Art. 25, U.N. Doc. A/RES/217(III) (Dec. 10, 1948), available at www.un.org/en/documents/udhr.

144 International Covenant on Economic, Social and Cultural Rights, G.A. Res. 2200 (XXI), Art. 12, U.N. GAOR, 21 Sess., Supp. No 16 , Doc. A/6316 (1967) reprinted in 6 I.L.M. 360 (1967) (entered into force Jan. 3, 1976), available at www2.ohchr.org/English/law/cescr.htm.

145 See Julian Sanchez, Ronald Dworkin, Heartless Libertarian?, JULIAN SANCHEZ (Sept, 21, 2011), http://www.juliansanchez.com/ 2011/09/21/ronald-dworkin-heartless-libertarian

("Unsurprisingly, [Dworkin] favors a national system of universal healthcare."); see also Richard Rorty, Looking Back, Looking Forward, THE NATION (Dec. 20, 2004), available at http://www.thenation.com/article/looking-backlooking-forward?page $=0,5$ (noting the "humiliation and misery of families without health insurance"); see also Robert W. Tabscott, Moral Man, Immoral Society: Reinhold Niebuhr, ST. LOUIS JoURNALISM REV. (May 1, 2009), available at http://www.thefreelibrary.com/Moral+man,+ immoral+society\%3A+Rheinhold+Niebuhr.-a0204683633) (noting that Reinhold Neibuhr advocated for health care for assembly line workers); see also Thomas J. Papadimos, Healthcare Access as a Right, not a Privilege: A Construct of Western Thought, PHIL., ETHICS, AND HUMAN. IN MED. (March 28, 2007), http://www.peh-med.com/content/pdf/1747- 
an argument in favor of universal health care that can be extrapolated from the thought of important philosophers are Meng Tzu's ideal of adequate social welfare, the categorical imperative of Immanuel Kant, and the theory of justice by John Rawls.

Meng Tzu advocates a theory of social welfare in which the "ruler" (government) is considerate of the needs of his subjects. ${ }^{146}$ This is true even when society is confronted with conflicting and competing interests. ${ }^{147}$ In an example provided by Meng Tzu, a student and teacher must engage in combat. The student faces a conflict of interest, for on the one hand he is duty-bound to destroy his teacher who is his political enemy. On the other hand, he should spare his teacher out of respect. Meng Tzu's solution is to have the student disarm his arrows, and then shoot them at his teacher. ${ }^{148}$ For Meng Tzu this is an acceptable solution because the student compromises the imperative to kill his teacher by doctoring his weapons so they cannot harm him,

5341-2-2.pdf ("[I]nequalities [in health care] will be tolerated only when such inequalities work to the advantage of society's most disadvantaged."); see also Jill Jacobs, Health Care Reflects a Jewish Obligation, JEWISH WEEK (Sept. 2009), (advocating that when poor people cannot pay for their medical care, the community sends a doctor and the medicine is paid for by a communal fund); see also JAMES Hughes, Buddhist Bioethics, in PRINCIPLES OF HEALTH CARE ETHICS 131-32 (R.E. Ashcroft, A. Dawson, H. Draper, \& J.R. McMillan eds., 2nd ed., John Wiley \& Sons, 2007), available at http://ieet.org/archive/buddhistbioethics.pdf; see also Stephen Foley, Tony Judt: I Am Not Pessimistic in the Very Long Run, THE INDEPENDENT (U.K.) (March 24, 2010), available at http://www. independent.co.uk/arts-entertainment/books/features/tony-judt-i-am-

not-pessimistic-in-the-very-long-run-1925966.html (stating that "healthcare reform is . . . self-evidently necessary"); see also Bhfrik, Happy Birthday Stephen Hawking, DAILY Kos (Jan. 8, 2012), http:// www.dailykos.com/story/2012/01/09/1052896/-Happy-Birthday-StephenHawking ("[Stephen Hawking] wouldn't be here today if it were it not for the N.H.S."); see also E-mail from Joseph Raz, Research Professor, King's College London (Feb. 24, 2012, 11:53 AM EST) (on file with author) ("[Healthcare] is a recognized human right, well entrenched in international law.").

146 See Meng-Tzu in MASTerpieces of World Philosophy 89

(Frank N. Magill ed., 1990).

147 See id. at 91-92.

148 See id. at 91. 
but still shoots them at him as a symbolic gesture of his teacher's status as his political enemy. In this way, the student, perhaps as a representative of the government, is able to balance two legitimate state interests. The first interest is the need for members of society to respect its teachers, while the second is the need for society to protect itself from enemies. The relevancy of Meng Tzu's thesis to national health care is unmistakable. Many Americans believe the debate on national health care is insurmountable due to the friction such health care would create between the right of all Americans to health care, and the seemingly competing right Americans have to be free from government intrusion over their choice of health care. ${ }^{149}$ Meng Tzu's hypothetical student's solution, being able to both honor his teacher and fight his enemy, can inform a compromise that would be the modified capitalistic American society I favor. Specifically, members in such a society would have their basic needs socialistically met, while still being able to work capitalistically for luxuries and a higher standard of living.

Second, Kant's Categorical Imperative is essentially a philosophical reformulation of the Golden Rule. ${ }^{150}$ Whereas the Golden Rule calls on one to not do anything she doesn't want anyone else to do to her, the Categorical Imperative posits one should not do anything she does not want anyone to do to anyone else. ${ }^{151}$ Clearly this maxim provides a legitimate rationale for universal health care because although some healthy and affluent individuals may not favor paying for the care of others, in the event such persons were to become sick and impoverished and unable to pay

149 See Megan Argo, Health Care: Caught Between Head and Heart, ETHICAL SPECTACLE (Sept. 2009), http://www.spectacle.org/0909/ argo.html.

150 See generally Thelma Z. Lavine, Reasonable Doubt, WASHINGTON POST, May 20, 2001, at 13, available at http:/www.tjhsst. edu/ jlamb/Kant-\%20Bio.pdf. (reviewing KANT: A BIOGRAPHY).

151 See Philip A. Pecorino, Ethics -The Categorical Imperative, http://www.qcc.cuny.edu/socialsciences/ppecorino/intro_text/Chapter\%20 8\%20Ethics/Categorical_Imperative.htm (last visited Jan. 31, 2013); see also Foundations of the Metaphysics of Morals, in MASTERPIECES OF WORLD PHILOSOPHY 336-43 (Frank N. Magill ed. 1990). 
their medical bills, they might very well change their minds and favor national coverage. ${ }^{152}$ Such a dynamic proves that the position of many opponents of national health care is untenable, even on their own terms, for many, if not most, such persons would truly not wish to be without access to health care in the event they could not pay for it. This provides the Kantian ground for why a program of national health care is reasonable.

In $A$ Theory of Justice, Rawls presents his Difference Principle, that in a just and fair society, individuals choose to live so that any advantage they collectively have does not infringe on the interests of the least advantaged among them. ${ }^{153}$ All examinations of health care under a Rawlsian analysis must therefore yield a system that, like government-executed health care, is accessible to all individuals, regardless of ability to pay, because to insist on the private insurance set up presently in place, would advantage those who can independently finance their health care over those who cannot.

\section{CONCLUSION}

A cogent reading of key constitutional provisions including the Preamble and the Commerce, Equal Protection, and Due Process clauses, as well as the Articles of Confederation and the Declaration of Independence, informs that Americans have a right to national, government-sponsored health care. Such a right to national health care is also supported by international constitutions and declarations and time-honored philosophical positions,

152 See generally Papadimos, supra note 140 (noting that the question of health care access for all persons is a moral interrogative that is "always there," especially as some who do not feel they need it today may very well need it tomorrow and that "we feel [the power of morality] even when we are most defying it . . . [and is] a compelling dictate that can be ignored, but never refuted").

153 Theory of Justice, in MASTERPIECES OF WORLD PHILOSOPHY 678; The Difference Principle, Political PHILOsophy.INFo, http://www. politicalphilosophy.info/differenceprinciple.html (last visited Oct. 14, 2012). 
such as are found in utilitarianism, the Categorical Imperative, Rawls' Theory of Justice, and Legal Realism. That all Americans and indeed citizens of the civilized world have a right to health care, irrespective of their ability to pay for insurance, is further guided by the fact that most Europeans and Canadians and many Asians presently have such access, and Americans already enjoy many essentially socialized government benefits, from police protection and sanitation services to public education. Finally, the history of health care in this country suggests an evolutionary trajectory from no insurance to private insurance to partially subsidized health care, ${ }^{154}$ as reflected in the gradually controlling Patient Protection and Affordability Care Act, ${ }^{155}$ a program that the Supreme Court has recently held constitutional. ${ }^{156}$

This evolution in health care is both encouraging and welcome because it demonstrates a growing and maturing understanding that morality and human rights are enmeshed with social responsibility. In fact, through this evolution, society has begun to fulfill a dynamic that the moral philosopher Marc Hauser notes at the individual level and calls a "norm of social responsibility," which is to "[h]elp people who can't help themselves."157

154 See STAY SMART: STAY HEALTHY, supra note 23.

155 See supra notes 44-48.

156 See Nat'l Fed'n of Indep. Bus. v. Sebelius, 132 S. Ct. 2566 (2012).

157 MARC. D. HAUSER, MORAL Minds 289 (2006). 